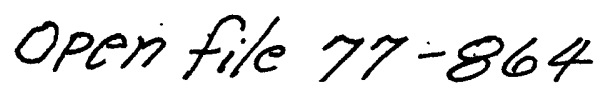

Notes: The Landsat MSS images used were processed in The Image Processing Facility, Branch of Astrogeologic Studies, Flagstaff, AZ. under the supervision of Pat Chavez, Jr. All frames are enhanced, highpass filtered $B / W$ versions of band SIX. They were further enhanced. by removing noise patterns, by applying a linear contrast stretch, and by lessening the effects of atmospheric haze. Taken together these processes tend to enhance high frequency tonal differences (Those occurring within small areas) so that the fine details of topographic relief are made more apparent. In addition, a correction was applied to make the sun angle more uniform across the area of the Appalachian basin and frames were geometrically rectified for compatibility with standard 2-degree topographic sheets on the transverse Mercator projection: The working scale is 1:500,000.

For this first-cut compilation, I have tried to incorporate as little interpretation as possible. Only the longer and/or more prominent lineaments from among many thousands were selected for this map. They are the lineaments recognized during the first hour of examination of each frame. However, by far the most prominent linear features in the area of the map are those resulting primarily from folding and thrust faulting in the Valley and Ridge province. These are not shown.

As drawn, the length of each line marking a lineament is a direct measure of the length of the feature by which the lineament is expressed. Dashed lines are used in two senses. First, where 
individual segments are as short or shorter than the length of the dash and secondly, where long segments of a lineament are so irregular in detail that it would be misleading to portray them with a continuous line.

Most of the lineaments shown are recognized primarily by topographic expressions, and most commonly as aligned straight segments of two or more streams or small rivers. Only in the Valley and Ridge and Blue Ridge provinces were lineaments distinguished primarily by tonal differences recognized. However, even these for the most part probably are vegetation patterns along small valleys whose relief is not visible at the resolution of the images.

The use of two line weights is an attempt (only partiy successful at best) to distinguish between lineaments that probably are structurally controlled and those that are less convincingly so. The former, while not necessarily the most prominent and readily recognizable, tend to be more continuous and more uniform in expression. However, the remarkably long, straight north-southtrending valleys in the Central Lowlands part of Ohio are exceptions. They are placed in the less convincing category and are shown by light weight lines. This was done because low topographic relief and glacial deposits masking the bedrock surface combine to effectively obscure any evidence of structural contro1. 


\section{. Reference}

de Witt, Wallace, Jr., Perry, W.J., Jr., and Wallace, L.G., 1975, 011 and gas data from Devonian and Silurian rocks of the Appalachian basin: U.S. Geol. Survey Misc. Geol. Inv. Map I-917-B.

Elder, C.H., Jeran, P.W., and Keck, D.A., 1974, Geologic structure analysis using radar imagery of the coal mining area of Buchanan County, Virginia: U.S. Bus. Mines Rept. Inv. 7869, 29 p.

Johnston, J.E., Miller, R.L., and Englund, K.J., 1975, Application of remote sensing to structural interpretations in the southern Appalachians: U.S. Geol. Survey Jour. Research v. 3, no. 3, p. 285-293. 
Probably structurally controlled. Dashed where individual segments are very short, i.e. shorter than dashes. Those identified by letters* are known to be faults.

\section{LANDSAT LINEAMENT}

Structural control is less certain, and topographic expression of many is weaker. Dashes used as above.

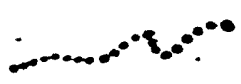

BOUNDARY BETWEEN CONTRASTING TERRAINS

Marks boundary between highly subdued topography characteristic of the Central Lowlands and Interior Plateaus to the west and more rugged (dissected) topography of the Appalachian Plateaus to the east.

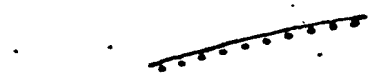

CREST OF PINE MOUNTAIN

(This topographic feature is shown for reference purposes.)

ror

WEST EDGE OF VALLLEY AND RIDGE PROVINCE

Line drawn along west flanks of westernmost steeply anticlinal mountains of the Valley and Ridge province. Approximates the "Appalachian structural front" of Price (1931).

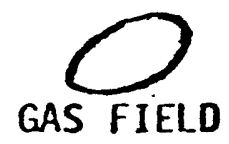

Outline of area producing gas from Devonian shale (de Witt. and others, 1975 ).

* B.B.C.F. = Bishop-Bradshaw Creek fault of Elder and others (1974). Also the Canebrake fault of Johnston and others (1975).

R.F.F. = Russell Fork fault.

, CO.F. = Coeburn fault of Johnston and others (1975). 